\title{
Utilization of sheep dung and rice straw with indigenous microbial agent to optimize vermicompost production and quality
}

\author{
YULI ASTUTI HIDAYATI ${ }^{1, \boldsymbol{v}}$, SITI NURACHMA ${ }^{2}$, DEDEN ZAMZAM BADRUZZAMAN ${ }^{1}$, \\ EULIS TANTI MARLINA ${ }^{1}$, ELLIN HARLIA ${ }^{1}$ \\ ${ }^{1}$ Department of Livestock Product Technology, Faculty of Animal Husbandry, Universitas Padjadjaran. Jl. Raya Bandung-Sumedang Km 21, Sumedang \\ 45363, West Java, Indonesia. Tel./fax.: +62-22-7798247, `email: yuliastuti@unpad.ac.id \\ ${ }^{2}$ Department of Livestock Production, Faculty of Animal Husbandry, Universitas Padjadjaran. Jl. Raya Bandung-Sumedang Km 21, Sumedang 45363 , \\ West Java, Indonesia
}

Manuscript received: 30 September 2021. Revision accepted: 23 November 2021.

\begin{abstract}
Hidayati YA, Nurachma S, Badruzzaman DZ, Marlina ET, Harlia E. 2021. Utilization of sheep dung and rice straw with indigenous microbial agent to optimize vermicompost production and quality. Biodiversitas 22: 5445-5451. Sheep dung is a useful by product that can be potentially processed into more useful products with minimal pollution. Vermicomposting is a waste processing method that produces Solid Organic Fertilizer and worm biomass as the raw materials for drugs and cosmetics. This research aimed to utilize the role of indigenous fungi and bacteria to determine the influence of $\mathrm{C} / \mathrm{N}$ ratio from sheep dung and rice straw mixture on vermicompost quality (N, P, K, Ca, Mg). This experimental research was conducted in a Completely Randomized Design with three treatments (T1: $\mathrm{C} / \mathrm{N}$ ratio of $25 ; \mathrm{T} 2: \mathrm{C} / \mathrm{N}$ ratio $30 ; \mathrm{T} 3: \mathrm{C} / \mathrm{N}$ ratio 35$)$ and six replicates for each treatment. Data so obtained were analyzed with ANOVA and Duncan's Multiple Range Test. The results showed that $\mathrm{C} / \mathrm{N}$ ratio had a noticeable influence on vermicompost quality. $\mathrm{C} / \mathrm{N}$ ratio 30 produced the highest vermicompost quality $(\mathrm{N}: 1.11 \pm 023381 \%$; $\mathrm{P}: 0.56 \pm 0.010328 \%$; $\mathrm{K}: 0.51 \pm$ $0.021369 \%$; Ca: $0.33 \pm 0.0248 \%$; Mg: $0.14 \pm 0.0228 \%$ ).
\end{abstract}

Keywords: C/N ratio, indigenous microbes, rice straw, sheep dung, vermicomposting

\section{INTRODUCTION}

Sheep is one of the most common livestock in Indonesia. The 2020 statistics of livestock in Indonesia showed that West Java province is home to most sheep population in Indonesia, accounting for 12.272.435 heads of sheep or $69.06 \%$ of the total population nationwide (17.769.084 heads of sheep) (Ditjen PKH 2020). Sheep farming inevitably produces dung that weighs approximately $7-8 \%$ of cattle body weight (Penakalapati et al. 2017) like ram (90-100 kg) and ewe (50-70 kg). In other words, a farm with 100 sheep $( \pm 60 \mathrm{~kg} / \mathrm{head})$ will produce \pm $420 \mathrm{~kg}$ of fecal waste per day which is required to be managed well to avoid harm to the environment. The uncontrolled decomposition of dung produces air polluting agents like ammonia, $\mathrm{H}_{2} \mathrm{~S}, \mathrm{CO}_{2}$, and $\mathrm{CH}_{4}$. When it enters the water system, the sheep dung increases the Biological Oxygen Demand and Chemical Oxygen Demand but decreases the Dissolved Oxygen. In addition, sheep dung promotes the survival of pathogenic bacteria in the soil which may cause many diseases. Therefore, dung required attention to be processed properly (Zainuddin et al. 2019).

The sheep dung contained indigenous microbes, including bacteria and fungi that can be utilized as decomposing agents if used in well controlled conditions. In the right quantity, Microbes in appropriate quantity can undergo an optimal decomposition process in controlled moisture content and humidity of the organic matter. AbuBakar and Ibrahim (2013) stated that good levels of C and
$\mathrm{N}$ fulfill the nutrient requirements of these indigenous and ultimately affect microbial activity. To obtain a good balance of $\mathrm{C} / \mathrm{N}$ ratio, sheep dung (a nitrogen source) cannot be processed singly but be incorporated with carbon sources. The optimum $\mathrm{C} / \mathrm{N}$ ratio is the main factor of composting quality (Dadi et al. 2019). The $\mathrm{C} / \mathrm{N}$ ratio of sheep dung is lower than the required level for processing (C/N 25 - 35). The $\mathrm{C} / \mathrm{N}$ ratio of sheep dung is $19.00 \pm 0.84$ (C/N 25 - 35) (Azim et al. 2014). Therefore, it is necessary to add another $\mathrm{C}$ source to increase $\mathrm{C} / \mathrm{N}$ ratio of sheep dung.

Rice straw is one of the agricultural wastes that potentially adds nutrients to the soil and provides carbon source. However, burning straws is more popular among farmers than processing them into fertilizer because it is difficult to incorporate a large amount of straw into the soil (Jin et al. 2020). Rice straw contains $40 \%$ C, $0.6 \%$ N, $0.1 \%$ $\mathrm{S}$, and $1.5 \% \mathrm{Si}$ (Ponnamperuma 1984) and has a cell wall that builds on $39.7 \%$ cellulose in dry weight, $25.2 \%$ hemicellulose, and 4.8\% lignin (Yang et al. 2020). The chemical complexity and the structure of straw make it difficult for microorganisms to decompose (Guo et al. 2018). Therefore, the straw needs shredding prior to mixture to allow a smooth composting process and to obtain quality compost (Roca-Pérez et al. 2009). Dung and rice straw can be composted with the help of anaerobic activity of indigenous microorganisms. Use of earthworms to compost organic material is another method that produces a solid organic fertilizer called vermicompost (Pathma and Sakthivel 2012). 
The growth and activity of indigenous microorganisms in vermicomposting require a balanced substrate $\mathrm{C} / \mathrm{N}$ ratio. Therefore, it is necessary to evaluate the effect of the $\mathrm{C} / \mathrm{N}$ ratio of the substrate according to the indigenous microorganism requirement through decomposition and vermicomposting. This study aimed to determine the impact of $\mathrm{C} / \mathrm{N}$ ratio of the mixture of sheep dung and rice straw on vermicompost quality (the content of $\mathrm{N}, \mathrm{P}, \mathrm{K}, \mathrm{Ca}$, $\mathrm{Mg}$ ) by utilizing the role of indigenous fungi and bacteria.

\section{MATERIALS AND METHODS}

\section{Substrate source}

Two substrates namely, sheep dung (source of $\mathrm{N}$ ) and rice straw (source of $\mathrm{C}$ ) collected from local farms and rice farmers residing around the area of Padjadjaran University, Jatinangor, Sumedang Regency, West Java, Indonesia were used in the present. The sheep dung was first air dried and mashed to reduce ammonium levels and inhibit the decomposition or vermicompost process. The rice straws were shredded into small pieces of $5-10 \mathrm{~cm}$ to allow an optimum decomposition (Garczyńska et al. 2020). Organic carbon was determined using the Walkley and black methods (Gelman et al. 2012) and total nitrogen concentration by Kjeldahl method (Abrams et al. 2014).

\section{Decomposition}

After being weighed, the prepared sheep dung and rice straw were combined to achieve $\mathrm{C} / \mathrm{N}$ ratios of 25,30 , and 35 . The formula for calculating the $\mathrm{C} / \mathrm{N}$ ratio (Azim et al. 2014) is as follows:

$$
\begin{aligned}
& \frac{C}{N}(\text { mixture })=\frac{\sum_{n=1}^{\infty}\left(Q_{n}\left[C_{n}\left(100-M_{n}\right)\right]\right)}{\sum_{n=1}^{\infty}\left(Q_{n}\left[N_{n}\left(1-M_{n}\right)\right]\right)} \\
& \frac{C}{N}(\text { mixture })=\mathrm{C} / \mathrm{N} \text { ratio of the resulting materials to } \\
& Q_{n} \quad=\text { Quantity of the fresh material (n) } \\
& C_{n} \quad=\text { Total carbon content of the dry material (n) } \\
& M_{n} \quad=\text { moisture content of the fresh material (n) } \\
& N_{n} \quad=\text { Total nitrogen content of the dry material (n) }
\end{aligned}
$$
compost

To maintained moisture content of the mixture between $55-60 \%$, the water content was determined using the gravimetric method at regular intervals. Each mixture was put into a sack, compacted, and let decomposed for 14 days while, measuring the temperature of the mixture on a daily basis (Mironov et al. 2021).

\section{Analysis of total bacteria and fungi}

Total bacteria and fungi were enumerated before and after the decomposition process to determine the activity of indigenous microbes during the decomposition. For microbiological analysis, $10 \mathrm{~g}$ of mixture sample was resuspended in $90 \mathrm{~mL}$ of sterile saline, then a 10 -fold serial dilution of the suspension was performed and appropriate dilution was plated on sterile growth media (Nutrient Agar and Potato Dextrose Agar) with a subsequent incubation for $48 \mathrm{~h}$ at $37^{\circ} \mathrm{C}$ (NA) and 5 days at $25^{\circ} \mathrm{C}$ (PDA) (Tamizhazhagan et al. 2016; Mironov et al. 2021).

\section{Vermicomposting}

As decomposition process was completed, the mixture was removed from the sack and air-dried for several days to release any ammonia that might have formed during decomposition (Mohammed-Nour et al. 2019). The decomposed mixture was put into a 44.5 x $35 \times 1.5 \mathrm{~cm}$ plastic box and the water content was maintained between $60-70 \%$ (Singh and Bhadauria 2012). After that, Eisenia fetida (Savigny 1826) earthworms (7-10\% of the total mixture) were put into the box. The vermicomposting process was carried out for at least 14 days, then the earthworms were separated from the mixture and weighed while, the vermicompost was tested further (Garczyńska et al. 2020)

\section{Determination of $\mathrm{P}, \mathrm{K}, \mathrm{Ca}$, and $\mathrm{Mg}$}

Macro elements such as Phosphate (P), Potassium (K), Calcium $(\mathrm{Ca})$, and Magnesium $(\mathrm{Mg})$ were determined in the vermicompost products. Total $\mathrm{P}, \mathrm{K}, \mathrm{Ca}$, and $\mathrm{Mg}$ was extracted with $\mathrm{HClO}_{4}$ and $\mathrm{HNO}_{3}$ (4:1 ratio). The concentration of $\mathrm{P}$ was measured with Molybdovanadate reagent and scanned by UV-VIS spectrophotometry at 822 wavelength ( Bhat et al. 2017; Moldes et al. 2007). The K, $\mathrm{Ca}$, and $\mathrm{Mg}$ concentration was measured using flame photometer in the diacid digest of the samples then determined by readings obtained from flame photometer using a standard curve (Bhat et al. 2017).

\section{Data analysis}

The experiment was conducted in a Completely Randomized Design and the data were subjected to Analysis of Variance. Any differences between treatments were further subjected to Duncan's multiple range test (Tamizhazhagan et al. 2016), and any differences among means for all traits were tested for significance at 5\% level (Farag et al. 2015). The statistical analysis was performed using IBM SPSS ver. 20.

\section{RESULTS AND DISCUSSION}

\section{Total bacteria on the mixed substrate of sheep dung and rice straw at various $\mathrm{C} / \mathrm{N}$ ratios}

Total bacteria from the mixture of sheep dung and rice straw (substrate) was detected to ensure the ability of bacteria to generate a decomposition of the organic material. Total bacteria in the mixture (before decomposition), after decomposition, and after vermicomposting are presented in Table 1.

The results of bacteria that have been isolated and identified at the onset and the end of the decomposition process and after the vermicomposting process are shown in Table 2. 
Table 1. Total bacteria on the mixed substrate of sheep dung and rice straw at various $\mathrm{C} / \mathrm{N}$ ratios

\begin{tabular}{cccc}
\hline \multirow{2}{*}{ Treatment } & \multicolumn{3}{c}{ Total bacteria } \\
\cline { 2 - 4 } & Mixture $\left(\times \mathbf{1 0}^{\mathbf{1 1}} \mathbf{C F U} / \mathbf{g}\right)$ & ${\text { After decomposition }\left(\times \mathbf{1 0}^{\mathbf{9}} \mathbf{C F U} / \mathbf{g}\right)}^{\text {After vermicomposting }\left(\times \mathbf{1 0}^{\mathbf{9}} \mathbf{C F U} / \mathbf{g}\right)}$ \\
\hline T1 & $197.16 \pm 9.32^{\mathrm{a}}$ & $107.83 \pm 7.67^{\mathrm{b}}$ & $47,5 \pm 4.75^{\mathrm{b}}$ \\
T2 & $211.16 \pm 10.59^{\mathrm{ab}}$ & $129.16 \pm 6.91^{\mathrm{c}}$ & $29 \pm 5.32 .32^{\mathrm{a}}$ \\
T3 & $220.88 \pm 17.75^{\mathrm{b}}$ & $99.5 \pm 4.32^{\mathrm{a}}$ & $50,33 \pm 4.67^{\mathrm{b}}$ \\
\hline
\end{tabular}

Note: Values are mean \pm SD of six replications; ${ }^{a-b}$ Different superscripts in the same row represent significant differences $(p<0.05)$; $T 1$ : $\mathrm{C} / \mathrm{N}$ ratio $25, \mathrm{~T} 2: \mathrm{C} / \mathrm{N}$ ratio $30, \mathrm{~T} 3: \mathrm{C} / \mathrm{N}$ ratio 35

Table 2. Identification of bacteria on various phase

\begin{tabular}{|c|c|}
\hline \multirow{2}{*}{ Mixture } & Process \\
\hline & $\begin{array}{cc}\text { After decomposition } & \text { After vermicomposting } \\
\end{array}$ \\
\hline Bacillus sp., Gram negative, no spore & Bacillus sp., Gram negative, subterminal spore Bacillus sp., Gram negative, no spore \\
\hline $\begin{array}{l}\text { Bacillus sp., Gram negative, sub terminal } \\
\text { spore }\end{array}$ & $\begin{array}{l}\text { Bacillus sp., Gram positive, subterminal spore } \begin{array}{l}\text { Streptobacillus sp., Gram negative, no } \\
\text { spore }\end{array}\end{array}$ \\
\hline $\begin{array}{l}\text { Streptobacillus sp., Gram negative, no spore } \\
\text { Staphylococcus sp., Gram negative, no spore }\end{array}$ & Streptobacillus sp., Gram negative, no spore \\
\hline
\end{tabular}

Total bacteria in the mixture of sheep dung and rice straw at the beginning of the decomposition (mixture) were indigenous bacteria that degraded the complex organic material into simpler organic forms. These results were higher than those found by Mironov et al. (2021) which stated the number of mesophilic microorganisms was $3 \mathrm{x}$ $10^{6} \mathrm{CFU} / \mathrm{g}$ and thermophilic microorganisms $4 \times 10^{5}$ $\mathrm{CFU} / \mathrm{g}$ in the initial phase of decomposition.

The total number of bacteria decreased after the decomposition process because of the changed temperature during the composting due to mesophilic bacteria activities. According to Ayilara et al. (2020), high temperatures are expected in the aerobic composting process to kill disease germs, pathogenic microorganisms and weed seeds in organic waste. Thermophilic bacteria are active in a range of $40-58^{\circ} \mathrm{C}$. In this study, thermophilic bacteria ceased to grow and then decreased because metabolic products had inhibited bacterial development or organic matter for bacterial nutrition had depleted. It is in line with $\mathrm{Wu}$ et al. (2020) which stated that the total organic matter and nitrate are the most important factors of bacterial and fungal population change during the composting process. The present study also confirms regarding interactions with indigenous microorganisms, the changes in $\mathrm{C} / \mathrm{N}$ ratio and temperature affect the survival of pathogenic microbes in the composting process.

The results showed that $\mathrm{T} 2(\mathrm{C} / \mathrm{N}$ ratio 30$)$ produced the least bacteria, namely $29 \times 10^{9} \mathrm{CFU} / \mathrm{g}$. In vermicomposting, microorganisms work biochemically and earthworms contribute to the direct stimulation through fermentation of organic matter. According to Ramnarain et al. (2019), in the vermicomposting process, earthworms replace the activity of microorganisms, thus increasing the rate of mineralization of organic materials rapidly. The growth of earthworms is inhibited by the availability of carbon sources in their food ingredients (Joseph 2019). As bacterial activity decreases with organic matter and ultimately the number of bacteria, Bacillus sp. and
Streptobacillus sp. are isolated at the end of the composting. Streptobacillus sp. degrade organic matter but Bacillus sp. help degrade organic matter in the decomposition process.

\section{Total fungi on the mixed substrate of sheep dung and rice straw at various $C / N$ ratios}

Fungi contribute at the beginning of decomposition. Fungi is the first microorganism that helps penetrate the enzymes of microorganisms in degrading cellulose. Total fungi in the mixture before decomposition, after decomposition, and after vermicomposting are presented in Table 3.

The results of fungi isolated and identified at the onset and the end of the decomposition process and after the vermicomposting process are shown in Table 4.

The total fungi from the decomposition results had the same effect $(p>0.05)$ on T1 and T3 treatments but were significantly different $(p<0.05)$ in T2. The decreased number of fungi at $\mathrm{C} / \mathrm{N}$ ratio 30 was due to the role of fungi as decomposers being replaced by earthworms that consume the nutrients to reproduce and migrate. According to Medina-Sauza et al. (2019), since, earthworms and microorganisms compete for carbon sources, earthworms replace the role of fungi as the lack of carbon required for its growth. Also, fungi decreased because earthworms consumed fungi as their selective feed (Domínguez and Gómez-Brandón 2012).

Based on our observations, the fungi isolated and identified at the mixture were Aspergillus niger van Tieghem 1867, Aspergillus flavus Link (1809), Neurospora sp., Trichoderma sp., and Mucor sp. These fungi are active at mesophilic temperatures $\left(27.8-38.63^{\circ} \mathrm{C}\right)$ similar to the initial temperature of composting. The fungi stop growing as the temperature hits thermophilic stage, but resume growing once it reaches mesophilic temperature. 
Table 3. Total fungi on the mixed substrate of sheep dung and rice straw at various $\mathrm{C} / \mathrm{N}$ ratios

\begin{tabular}{cccc}
\hline \multirow{2}{*}{ Treatment } & \multicolumn{3}{c}{ Total fungi } \\
\cline { 2 - 4 } & Mixture $\left(\times \mathbf{1 0}^{\mathbf{1 1}} \mathbf{C F U} / \mathbf{g}\right)$ & ${\text { After decomposition }\left(\times \mathbf{1 0}^{\mathbf{9}} \mathbf{C F U} / \mathbf{g}\right)}^{\text {After vermicomposting }\left(\times \mathbf{1 0}^{\mathbf{9}} \mathbf{C F U} / \mathbf{g}\right)}$ \\
\hline T1 & $27.34 \pm 4.4572^{\mathrm{a}}$ & $3.67 \pm 1.21^{\mathrm{a}}$ & $4.83 \pm 2.578^{\mathrm{b}}$ \\
T2 & $28.17 \pm 3.0605^{\mathrm{a}}$ & $6.17 \pm 1.17^{\mathrm{b}}$ & $2.50 \pm 3.234^{\mathrm{a}}$ \\
T3 & $29.83 \pm 3.1885^{\mathrm{a}}$ & $4.33 \pm 1.03^{\mathrm{a}}$ & $4.83 \pm 2.678^{\mathrm{b}}$ \\
\hline
\end{tabular}

Note: Values are mean \pm SD of six replications; ${ }^{a-b}$ Different superscripts in the same row represent significant differences ( $\mathrm{p}<0.05$ ); $\mathrm{T} 1$ : $\mathrm{C} / \mathrm{N}$ ratio $25, \mathrm{~T} 2: \mathrm{C} / \mathrm{N}$ ratio $30, \mathrm{~T} 3: \mathrm{C} / \mathrm{N}$ ratio 35

The fungi isolated after the decomposition process were A. flavus, A. niger, and Trichoderma sp. At the end of the vermicomposting process, fungi that could be isolated and identified were A. flavus, A. niger, and Neurospora sp. Vermicomposting process provided a suitable environment for the fungi to grow at $20-29^{\circ} \mathrm{C}$ (Kaplan et al. 1980).

\section{Changes in the temperature and $\mathrm{C} / \mathrm{N}$ ratio at decomposition of dung of sheep and rice straw at various $C / N$ ratios}

The decomposition of sheep dung and rice straw mixture (substrate) by indigenous microorganisms results in temperature change and a decrease in the $\mathrm{C} / \mathrm{N}$ ratio which illustrated the activity of indigenous microorganisms in degrading the substrate organic matter. The temperature and $\mathrm{C} / \mathrm{N}$ ratios achieved in the decomposition process of sheep dung and rice straw mixture with different $\mathrm{C} / \mathrm{N}$ ratios are presented in Figure 1 and Figure 2, respectively.

In the decomposition process, the temperature in all treatments was observed between $32^{\circ} \mathrm{C}-34^{\circ} \mathrm{C}$. The temperature in $\mathrm{T} 1$ and $\mathrm{T} 2$ rose to $60^{\circ} \mathrm{C}$ on days 2 and 4 , then decreased up to $27-28^{\circ} \mathrm{C}$ on day 14 . Meanwhile, the temperature in $\mathrm{T} 3$ continued to increase until day 5 , but started to decrease on day $7\left(56^{\circ} \mathrm{C}\right)$ and keep going until day $14\left(28^{\circ} \mathrm{C}\right)$. It indicated organic matter degradation in the substrate of sheep dung and rice straw mixture in all treatments. In T3, the temperature took longer to decrease than in $\mathrm{T} 1$ and $\mathrm{T} 2$, presumably because organic material in T3 contained more carbon, requiring a longer degradation process. These results are in accordance with Topal et al. (2016) and Azim et al. (2018) which stated that the biodegradation process will be followed by an increase in temperature.

The initial $\mathrm{C} / \mathrm{N}$ ratio in $\mathrm{T} 1, \mathrm{~T} 2$, and $\mathrm{T} 3$ was 25,30 , and 35 , respectively, and decreased to $22-24$ as the decomposition process, occurred. It was evident that organic matter was degraded during decomposition process as indicated by temperature change. Similarly, Nayak et al. (2013); Nunes et al. (2016) and Pourzamani and Ghavi (2016) reported a decrease in $\mathrm{C} / \mathrm{N}$ ratio during the vermicomposting process from various organic waste.

Changes in temperature during the decomposition process were caused by the heat generated from the activity of mesophilic microorganisms. It was in line with Galitskaya et al. (2017) that the activity of heat-generating microorganisms would increase the temperature above $40^{\circ} \mathrm{C}$, indicative of organic matter degradation. The heat generated during the thermophilic phase can inhibit pathogenic microbes $\left(>55^{\circ} \mathrm{C}\right)$ and weed seeds $\left(>62^{\circ} \mathrm{C}\right)$.

\section{Effect of $\mathrm{C} / \mathrm{N}$ ratio on vermicomposting of sheep dung and rice straw mixture on earthworm biomass}

In vermicomposting, earthworms decompose organic material on the substrate to grow and become earthworm biomass at the end of the process. Earthworm biomass data from vermicomposting mixture of sheep dung and rice straw at various $\mathrm{C} / \mathrm{N}$ ratios are presented in Table 5 . The results showed that the $\mathrm{C} / \mathrm{N}$ ratio had no significant effect $(p>0.05)$ on the biomass of earthworms in T1 and T2 but was significantly different in T3 treatment. The T1 and T2 treatments produced higher earthworm biomass, because $\mathrm{T} 2$ was assumed to have the appropriate $\mathrm{C} / \mathrm{N}$ ratio for the degradation of organic matter substrate by indigenous microorganisms and earthworms. These findings are in line with Nayak et al. (2013), which stated that the $\mathrm{C} / \mathrm{N}$ ratio played a vital role in the composting process. The best compost was produced from $\mathrm{C} / \mathrm{N}$ ratio 30 using sewage sludge mixed with livestock manure and sawdust. According to Aira et al. (2006), the $\mathrm{C} / \mathrm{N}$ ratio affects the size of the earthworm population.

Table 4. Identification of fungi on various phase

\begin{tabular}{lll}
\hline \multicolumn{1}{c}{ Mixture } & \multicolumn{1}{c}{$\begin{array}{c}\text { After } \\
\text { decomposition }\end{array}$} & \multicolumn{1}{c}{$\begin{array}{c}\text { After } \\
\text { vermicomposting }\end{array}$} \\
\hline Aspergillus flavus & Aspergillus flavus & Aspergillus flavus \\
Aspergillus niger & Aspergillus niger & Aspergillus niger \\
Neurospora sp. & Trichoderma sp. & Neurospora sp. \\
Trichoderma sp. & & Trichoderma sp. \\
Mucor sp. & & \\
\hline
\end{tabular}

Table 5. Average biomass of earthworms from vermicomposting of sheep dung and rice straw mixture at various $\mathrm{C} / \mathrm{N}$ ratios

\begin{tabular}{cc}
\hline Treatment & Earthworms biomass $(\mathrm{g})$ \\
\hline T1 & $112.67 \pm 2.33^{\mathrm{b}}$ \\
T2 & $114.83 \pm 2.78^{\mathrm{b}}$ \\
T3 & $105.17 \pm 1.94^{\mathrm{a}}$ \\
\hline
\end{tabular}

Values are mean \pm SD of 4 replications; a-e Different superscripts in the same row represent significant differences $(\mathrm{p}<0.05)$; T1: $\mathrm{C} / \mathrm{N}$ ratio $25, \mathrm{~T} 2: \mathrm{C} / \mathrm{N}$ ratio $30, \mathrm{~T} 3: \mathrm{C} / \mathrm{N}$ ratio 35 
Table 6. Effect of $\mathrm{C} / \mathrm{N}$ ratio on vermicomposting of sheep dung and rice straw mixture to $\mathrm{N}, \mathrm{P}, \mathrm{K}, \mathrm{Ca}$ and $\mathrm{Mg}$ contents in vermicompost

\begin{tabular}{cccccc}
\hline Treatment & $\mathbf{N}(\boldsymbol{\%})$ & $\mathbf{P}(\boldsymbol{\%})$ & $\mathbf{K}(\boldsymbol{\%})$ & $\mathbf{C a}(\boldsymbol{\%})$ & $\mathbf{M g}(\boldsymbol{\%})$ \\
\hline T1 & $0.95 \pm 0.01^{\mathrm{a}}$ & $0.36 \pm 0.01^{\mathrm{a}}$ & $0.49 \pm 0.02^{\mathrm{a}}$ & $0.34 \pm 0.04^{\mathrm{a}}$ & $0.12 \pm 0.02^{\mathrm{c}}$ \\
T2 & $1.11 \pm 0.23^{\mathrm{c}}$ & $0.56 \pm 0.01^{\mathrm{c}}$ & $0.51 \pm 0.02^{\mathrm{ab}}$ & $0.33 \pm 0.02^{\mathrm{a}}$ & $0.14 \pm 0.02^{\mathrm{b}}$ \\
T3 & $0.98 \pm 0.01^{\mathrm{b}}$ & $0.44 \pm 0.01^{\mathrm{b}}$ & $0.53 \pm 0.03^{\mathrm{b}}$ & $0.32 \pm 0.01^{\mathrm{a}}$ & $0.14 \pm 0.02^{\mathrm{a}}$ \\
\hline
\end{tabular}

\section{The effect of $\mathrm{C} / \mathrm{N}$ ratio on vermicomposting of sheep dung and rice straw mixture on the quality of vermicompost ( $\mathrm{N}, \mathrm{P}, \mathrm{K}, \mathrm{Ca}$, and $\mathrm{Mg}$ contents)}

The decomposed products are used by earthworms and microorganisms for their growth and activities to convert simple organic materials into nutrients that can be absorbed by the plant roots. According to Bidabadi (2018), the nutrients as an indicator of in vermicompost include nitrate, phosphorus, potassium, calcium, and dissolved magnesium. The content of $\mathrm{N}, \mathrm{P}, \mathrm{K}, \mathrm{Ca}$ and $\mathrm{Mg}$ in the vermicomposting process of sheep dung and rice straw mixture with various $\mathrm{C} / \mathrm{N}$ ratios are presented in Table 6 .

The results of present study showed that $\mathrm{T} 2$ had the highest $\mathrm{N}$ content $(1.11 \%)$ in vermicompost because the organic matter in the substrate was parallel with the number and types of indigenous microorganisms and earthworms, thus allowing a smooth decomposition of the substrate organic matter and mineralization process of forming N. Similarly, Ayilara et al. (2020) observed that a high $\mathrm{C} / \mathrm{N}$ ratio in a substrate is not suitable for the growth and activity of microorganisms in degrading organic matter. According to Kaushik and Garg (2003), the symbiotic activity between indigenous microorganisms and enzymes in the intestines of earthworms transform organic matter into macronutrients $(\mathrm{N}, \mathrm{P}$, and $\mathrm{K})$ in vermicompost.

The $\mathrm{P}$ content in vermicompost reached the highest value $(0.56 \%)$. The $\mathrm{P}$ content is derived from sheep dung and rice straw which contain protein that breaking down during vermicomposting process. In vermicomposting process, the $\mathrm{P}$ element is used by microorganisms and worms for growth and activities to degrade the substrate, then a mineralization process occurs which is left in the vermicompost. This finding supports Goswami et al. (2013) and Suthar (2009) that phosphate in the substrate is converted into $\mathrm{P}$ by phosphatase in the intestines of the substrate during the vermicomposting process worms and microorganisms.

The Potassium $(\mathrm{K})$ content was significantly different in T3 $(p<0.05)$, Ca was not significantly different across treatments $(p>0.05)$, but $\mathrm{Mg}$ was significantly different across treatments $(p<0.05)$. K content in vermicompost is derived from potassium which is in the forage from sheep dung and rice straw and is influenced by the vermicomposting process. Pattnaik and Reddy (2010) reported that $\mathrm{K}$ content changed differently according to the types of green waste used as a substrate. While incorporating plant forage (Neem leave, Parthenium, Sialkanta) into cow dung in vermicomposting, increase in $\mathrm{K}$ content takes place (Mistry et al. 2015), the total $\mathrm{K}$ in vermicompost is dependent on the raw materials and correlated with activity of earthworms and microorganisms during vermicomposting (Yan et al. 2013).

$\mathrm{Ca}$ and other minerals in vermicompost are influenced by the organic matter of substrate composition and the activity of plant worms and microorganisms during vermicomposting. Similarly, Yan et al. (2013) stated that high $\mathrm{Ca}$ content in sago waste stimulates earthworms to produce vermicompost with high $\mathrm{Ca}$ content. According to Pattnaik and Reddy (2010), Ca content in vermicompost is obtained from the substrate and the activity of earthworms, and $\mathrm{Mg}$ is associated with earthworm activity. Furthermore, Ramnarain et al. (2019) stated that the amount of $\mathrm{Mg}$ in vermicompost is higher than the substrate due to the activity of earthworms.

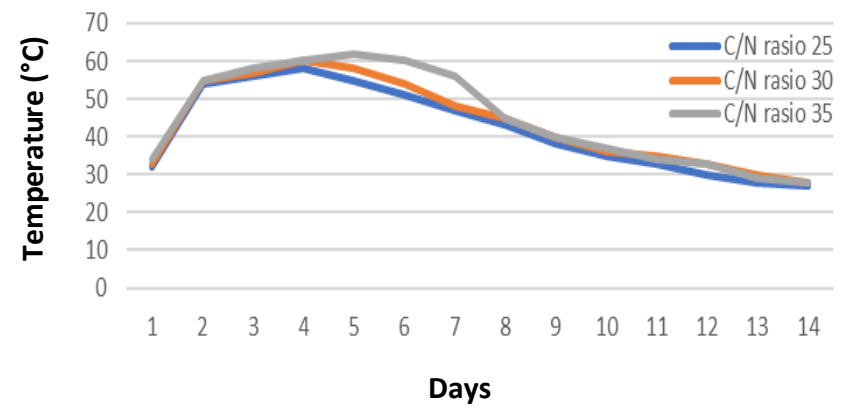

Figure 1. Temperature Changes in decomposition of Sheep dung and rice mixtures at various $\mathrm{C} / \mathrm{N}$ ratios

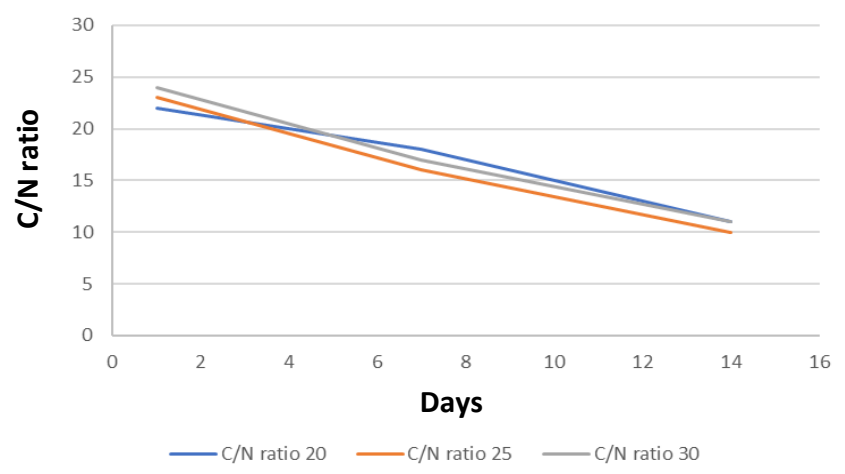

Figure 2. $\mathrm{C} / \mathrm{N}$ ratio changes in the early decomposition of mixed sheep dung and rice straw 


\section{ACKNOWLEDGEMENTS}

The authors express their gratitude to the Rector of Universitas Padjadjaran, West Java, Indonesia and the Directorate Research and Community Services Universitas Padjadjaran for the funding under the Competitive Grant Research for Lecturers in Universitas Padjadjaran.

\section{REFERENCES}

Abrams D, Metcalf D, Hojjatie M. 2014. Determination of Kjeldahl nitrogen in fertilizers by AOAC official method SM 978.02: Effect of copper sulfate as a catalyst. J AOAC Intl 97 (3): 764-767. DOI 10.5740/jaoacint.13-299.

Abu-Bakar NA, Ibrahim N. 2013. Indigenous microorganisms production and the effect on composting process. In AIP Conf Proc 1571 (1): 283-286. DOI: 10.1063/1.4858669. [Malaysia]

Aira M, Monroy F, Domínguez J. 2006. C to N ratio strongly affects population structure of Eisenia fetida in vermicomposting systems. Eur J Soil Biol 42: 127-131. DOI: 10.1016/j.ejsobi.2006.07.039.

Ayilara MS, Olanrewaju OS, Babalola OO, Odeyemi O. 2020. Waste management through composting: Challenges and potentials. Sustainability 12 (11): 1-23. DOI: 10.3390/su12114456.

Azim K, Ouyahia K, Amellouk A, Perissol C, Thami-Alami I, Soudi, B. 2014. Dynamic composting optimization through $\mathrm{C} / \mathrm{N}$ ratio variation as a startup parameter. In: Rahmann G, Aksoy U (eds). Proceedings of the 4th ISOFAR Scientific Conference. 'Building Organic Bridges', at the Organic World Congress, Istanbul, 13-15 October 2014. [Turkey]

Azim K, Soudi B, Boukhari S, Perissol C, Roussos S, Alami IT. 2018. Composting parameters and compost quality: a literature review. Org Agric 8 (2): 141-158. DOI: 10.1007/s13165-017-0180-z.

Bhat SA, Singh J, Vig AP. 2017. Instrumental characterization of organic wastes for evaluation of vermicompost maturity. J Anal Sci Technol 8 (1): 1-12. DOI: $10.1186 / \mathrm{s} 40543-017-0112-2$

Bidabadi SS. 2018. Waste management using vermicompost derived liquids in sustainable horticulture. Trends Hortic 1 (3). DOI 10.24294/th.v1i3.175.

Dadi D, Daba G, Beyene A, Luis P, Van der Bruggen B. 2019 Composting and co-composting of coffee husk and pulp with sourceseparated municipal solid waste: a breakthrough in valorization of coffee waste. Intl J Recycl Org Waste Agric 8 (3): 263-277. DOI: 10.1007/s40093-019-0256-8.

Ditjen PKH. 2020. Livestock and Health Statistics 2020 www.ditjenpkh.pertanian.go.id

Domínguez J, Gómez-Brandón M. 2012. Vermicomposting: Composting with Earthworms to Recycle Organic Wastes. Mangagemnet of Organic Waste. DOI: 10.5772/33874

Farag AA, Ahmed M, Salman, Hashem FA, Abdrabbo MAA. 2015 Utilization of rice straw and vermicompost in vegetable. Glob J Adv Res 2 (5): 800-813.

Galitskaya P, Biktasheva L, Saveliev A, Grigoryeva T, Boulygina E, Selivanovskaya S. 2017. Fungal and bacterial successions in the process of co-composting of organic wastes as revealed by 454 pyrosequencing. PLoS One 12 (10): e0186051. DOI: 10.1371/journal.pone.0186051.

Garczyńska M, Kostecka J, Paczka G, Hajduk E, Mazur-Paczka A, But KR. 2020. Properties of vermicomposts derived from Cameroon sheep dung. Appl Sci 10 (15): 1-14. DOI: 10.3390/app10155048.

Gelman F, Binstock R, Halicz L. 2012. Application of the Walkley-Black titration for the organic carbon quantification in organic rich sedimentary rocks. Fuel 96: 608-610. DOI: 10.1016/j.fuel.2011.12.053.

Goswami L, Patel AK, Uma, Dutta G, Bhattacharyya P, Gogoi N, Satya SB. 2013. Hazard remediation and recycling of tea industry and paper mill bottom ash through vermiconversion. Chemosphere 92 (6): 708 713. DOI: 10.1016/j.chemosphere.2013.04.066.

Guo T, Zhang Q, Ai C, Liang G, He P, Zhou W. 2018. Nitrogen enrichment regulates straw decomposition and its associated microbial community in a double-rice cropping system. Sci Rep 8 (1): 1-12. DOI: $10.1038 / \mathrm{s} 41598-018-20293-5$.
Jin Z, Shah T, Zhang L, Liu H, Peng S, Nie L. 2020. Effect of straw returning on soil organic carbon in rice-wheat rotation system: A review. Food Energy Secur 9 (2): 1-13. DOI: 10.1002/fes3.200.

Joseph PV. 2019. Efficacy of different substrates on vermicompost production: A biochemical analysis. In Organic Fertilizers-History, Production and Applications. IntechOpen. DOI: 10.5772/intechopen.86187.

Kaplan DL, Hartenstein R, Neuhauser EF, Malecki MR. 1980. Physicochemical requirements in the environment of the earthworm Eisenia foetida. Soil Biol Biochem 12 (4): 347-352. DOI: 10.1016/0038-0717(80)90008-5.

Kaushik P, Garg VK. 2003. Vermicomposting of mixed solid textile mill sludge and cow dung with the epigeic earthworm Eisenia foetida. Bioresour Technol 90 (3): 311-316. DOI: 10.1016/S09608524(03)00146-9.

Medina-Sauza R, Álvarez-Jiménez M, Delhal A, Reverchon F, Blouin M, Guerrero-Analco JA, Cerdán CR, Guevara R, Villain L, Barois I. 2019. Earthworms building up soil microbiota: a review. Front Environ Sci 7: 1-20. DOI: 10.3389/fenvs.2019.00081.

Mironov V, Vanteeva A, Merkel A. 2021. Microbiological activity during co-composting of food and agricultural waste for soil amendment. Agronomy 11 (5): 928. DOI: 10.3390/agronomy11050928.

Mistry J, Mukhopadhyay AP, Baur, GN. 2015. Status of N P K in vermicompost prepared from two common weed and two medicinal plants. Intl J Appl Sci Biotechnol 3 (2): 193-196. DOI: 10.3126/ijasbt.v3i2.12533.

Mohammed-Nour A, Al-Sewailem M, El-Naggar AH. 2019. The influence of alkalization and temperature on Ammonia recovery from cow manure and the chemical properties of the effluents. Sustainability 11 (8): 2441. DOI: 10.3390/su11082441.

Moldes A, Cendón Y, Barral MT. 2007. Evaluation of municipal solid waste compost as a plant growing media component, by applying mixture design. Bioresour Technol 98 (16): 3069-3075. DOI: 10.1016/j.biortech.2006.10.021.

Nayak AK, Varma VS, Kalamdh A. 2013. Effects of various C/N ratios during vermicomposting of sewage sludge using Eisenia fetida. J Environ Sci Technol 6 (2): 63-78. DOI: 10.3923/jest.2013.63.78.

Nunes RR, Bontempi RM, Mendonça G, Galetti G, Rezende MOO. 2016. Vermicomposting as an advanced biological treatment for industrial waste from the leather industry. J Environ Sci Health - Part B 51 (5): 271-277. DOI: $10.1080 / 03601234.2015 .1128737$.

Pathma J, Sakthivel N. 2012. Microbial diversity of vermicompost bacteria that exhibit useful agricultural traits and waste management potential. SpringerPlus 1 (1): 26. DOI: 10.1186/2193-1801-1-26.

Pattnaik S, Reddy MV. 2010. Nutrient status of vermicompost of urban green waste processed by three earthworm species- Eisenia fetida, Eudrilus eugeniae, and Perionyx excavatus. Appl Environ Soil Sci 2010: 1-13. DOI: 10.1155/2010/967526

Penakalapati G, Swarthout J, Delahoy MJ, McAliley L, Wodnik B, Levy K, Freeman MC. 2017. Exposure to animal feces and human health: A systematic review and proposed research priorities. Environ Sci Technol 51 (20): 11537-11552. DOI: 10.1021/acs.est.7b02811.

Ponnamperuma FN. 1984. Straw as a source of nutrients for wetland rice. Organic matter and rice.

Pourzamani H, Ghavi M. 2016. Effect of rice bran on the quality of vermicompost produced from food waste. Intl J Environ Health Eng 5 (1): 13. DOI: $10.4103 / 2277-9183.190639$.

Ramnarain YI, Ansari AA, Ori L. 2019. Vermicomposting of different organic materials using the epigeic earthworm Eisenia foetida. Intl $\mathbf{J}$ Recycl Org Waste Agric 8 (1): 23-36. DOI: 10.1007/s40093-0180225-7.

Roca-Pérez L, Martínez C, Marcilla P, Boluda R. 2009. Composting rice straw with sewage sludge and compost effects on the soil-plant $\begin{array}{lllll}\text { system. } & \text { Chemosphere } 75 \text { (6): 781-787. DOI: }\end{array}$ 10.1016/j.chemosphere.2008.12.058.

Singh D, Bhadauria S. 2012. Quantitative and qualitative distribution of bacteria in vermicompost produced by different organic wastes. Nat Environ Pollut Technol 11 (2): 331-334.

Suthar S. 2009. Bioremediation of agricultural wastes through vermicomposting. Bioremediat J 13 (1): 21-28. DOI: $10.1080 / 10889860802690513$

Tamizhazhagan V, Pugazhendy K, Sakthidasan V, Revathi K, Baranitharan M. 2016. Investigation of microbial count in the soil and earthworm gut (Eudrilus eugeniae). Innov J Agr Sci 4 (3): 7-9. 
Topal EI, Ünlü A, Topal M. 2016. Effect of aeration rate on elimination of coliforms during composting of vegetable-fruit wastes. Intl J Recycl Org Waste Agric 5 (3): 243-249. DOI: 10.1007/s40093-016-0134-6.

Wu X, Ren L, Luo L, Zhang J, Zhang L, Huang H. 2020. Bacterial and fungal community dynamics and shaping factors during agriculturalwaste composting with zeolite and biochar addition. Sustainability 12 (17): 7082. DOI: $10.3390 / \mathrm{su} 12177082$.

Yan YW, Azwady AAN, Shamsuddin ZH, Muskhazli M, Suraiini AA, Teng SK. 2013. Comparison of plant nutrient contents in vermicompost from selected plant residues. Afr J Biotechnol 12 (17): 2207-2214. DOI: 10.5897/AJB11.3164.

Yang X, Zhao J, Liang J, Zhu J. 2020. Efficient and selective catalytic conversion of hemicellulose in rice straw by metal catalyst under mild conditions. Sustainability 12 (24): 1-14. DOI: $10.3390 /$ su 122410601.

Zainuddin N, Maarif MS, Rianic E, Noord SM. 2019. Water pollution from the activity of large-ruminant Animal Quarantine Installation (AQI) in its receiving water body. Trop Anim Sci J 42 (1): 68-75. DOI: $10.5398 /$ tasj.2019.42.1.68. 